\title{
USING NATURAL DISASTERS TO INSTIGATE RADICAL POLICY CHANGES - THE EFFECT OF FUKUSHIMA NUCLEAR POWER PLANT ACCIDENT ON NUCLEAR ENERGY POLICIES
}

Zoran Milošević, Miroslav Vesković, Milivoj B. Gavrilov, Tin Lukić, Slobodan B. Marković

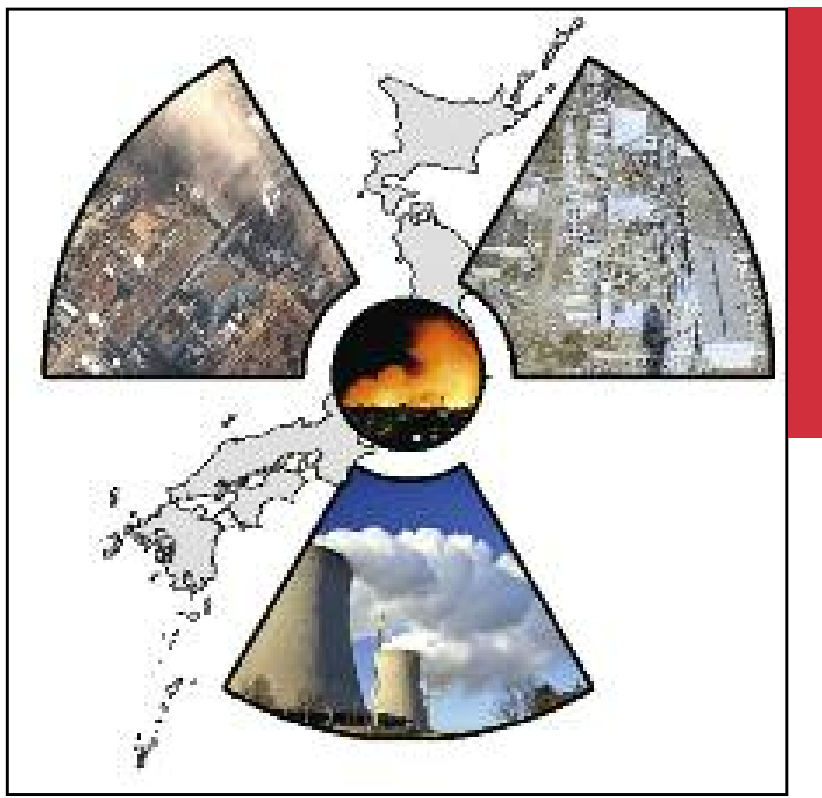

The impact of the Fukushima accident in Japan. 


\section{Using natural disasters to instigate radical policy changes - the effect of Fukushima nuclear power plant accident on nuclear energy policies}

DOI: $10.3986 /$ AGS53303

UDC: 91:504(520Fukušima) 621.039.58:550.34(520Fukušima)

COBISS: 1.02

ABSTRACT: Natural disasters and their effects have evolved to reflect the complexities of the physical and human environments, and their interactions in the modern world. After the earthquake and the tsunami of the Fukushima Daiichi nuclear reactors in March 2011 activists, lobbyist and reporters were quick to expose nuclear technology and demand if not an immediate closure, than at least a gradual phasing out of nuclear power plants. Further research on topics such as the safety of nuclear power plants, the environmental and social effects of radioactive contamination, and the potential of nuclear energy as a world power source has a critical role in this ongoing debate in order to reduce consumption of fossil fuels, and continuing rise in national energy demands for providing powerful motivators in the search for alternative energy sources.

KEY WORDS: natural disasters, nuclear energy, nuclear plant, Fukushima (Tohoku) earthquake, tsunami

ADDRESSES:

Zoran Milošević, Ph. D.

Department of Geography, Tourism and Hotel Management

Faculty of Sciences

University of Novi Sad

Trg Dositeja Obradovića 3

21000 Novi Sad, Serbia

E-mail: ZMilosevic@kbcat.com

Miroslav Vesković, Ph. D.

Department of Physics

Faculty of Sciences

University of Novi Sad

Trg Dositeja Obradovića 4

21000 Novi Sad, Serbia

E-mail: veskovic@df.uns.ac.rs

Milivoj B. Gavrilov, Ph. D.

Department of Geography, Tourism and Hotel Management

Faculty of Sciences

University of Novi Sad

Trg Dositeja Obradovića 3

21000 Novi Sad, Serbia

E-mail: milivoj.gavrilov@yahoo.com

Tin Lukić, M. Sc.

Department of Geography, Tourism and Hotel Management

Faculty of Sciences

University of Novi Sad

Trg Dositeja Obradovića 3

21000 Novi Sad, Serbia

E-mail: lukic021@gmail.com 
Slobodan B. Marković, Ph. D.

Department of Geography, Tourism and Hotel Management

Faculty of Sciences

University of Novi Sad

Trg Dositeja Obradovića 3

21000 Novi Sad, Serbia

E-mail: slobodan.markovic@dgt.uns.ac.rs

\section{Contents}

1 Introduction - using crises to foster causes 184

2 Fukushima nuclear accident 184

3 Post-Fukushima changes in nuclear energy policy - country-by-country $\quad 186$

4 Developing World - unaffected 186

5 Conclusion 187

6 Acknowledgment 188

7 References 188 


\section{Introduction - using crises to foster causes}

Natural disasters for all the tragedy that they entail, have long been used by political elites to further causes that until then may not have been enforceable, and implement policies that go beyond legitimate response to disaster. This practice has even been coined as a phrase »Never waste a good crisis«. The origins of the quote are obscure and it has been attributed to US President Theodore Roosevelt, Chicago's Mayor Rahm Emanuel and many others.

This doctrine however has recently received a much more profound rendering (Klein 2007).

Crises can be used by Governments to advance policies that they desired, or Government can be pushed into creating a new policy under the influence of shifting public opinion, extensive media coverage and the pressure exerted by various activist groups, who take advantage of the situation to advance their political agendas. Non-opportunistic, objective and prudent responses to crises are of course numerous, and arguably prevailing, although researching this particular hypothesis may produce interesting results. The lessons from the past however, seem to show that in the later case Governments under pressure tend to make decisions that drift towards exerting too much caution.

The damage of the Fukushima Daiichi nuclear reactors in March 2011 was no exception. Although the earthquake and the tsunami claimed the lives of more than 18,000 people, the topic that dominated media headlines was not as much the scale of this disaster, as it was the effect that it had on the nuclear station. Activists, lobbyist and reporters were quick to expose nuclear technology and demand if not immediate closure, than at least gradual phasing out of nuclear power plants.

To the analytical, and especially to the scientific mindset, it may be difficult to understand the basis for general mistrust of nuclear energy, which is probably rooted in some collective psychology originating from the way the technology was first developed and applied. Siegrist and Visschers (2011) particularly researched the psychology of public reaction to Fukushima and found, among other their conclusions, that a person's attitude can be predicted from his/her pre-accident stance on nuclear power.

Whatever the reason, the fact is that even in the absence of accidents nuclear power remains an object of deep public suspicion, even though it is seen as an important source of clean energy. It contributes significantly to national power supply in several EU countries: Belgium (51\%), France (74\%), Slovakia (52\%), and Slovenia (39\%) (Internet 1).

\section{Fukushima nuclear accident}

On $11^{\text {th }}$ March, 2011, an earthquake of 9.0 Richter scale magnitude occurred just off Japan's east coast. The massive tremor created a tsunami that was about 7 meters in height (McKenzie and Jackson 2012), which overwhelmed the seawall protecting the city of Fukushima and the Daiichi nuclear power station (Figure 1). Following a power failure caused by the earthquake, the tsunami destroyed the back-up cooling facilities and caused subsequent reactor meltdown and radioactive release. The fire in Daiichi's reactor was reminiscent of those that burned at Chernobyl, the site of the only other INES scale "Event Level 7« nuclear accident in history (Internet 2).

Echoing the Chernobyl disaster, the public opinion was quickly created demanding radical changes to nuclear safety and nuclear policies in general. The heightened public perception was largely created by activities of anti-nuclear campaigners and extensive media coverage, and supported by the impact of the accident on geopolitical relations in Japan and in the nearby countries into which the contamination could spread.

Several investigations of the Daiichi disaster were launched and reported. A hearing before the Japanese National Academy of Sciences showed that the initial meltdown of one of the six boiling water reactors took place within 11 hours of the earthquake (Internet 3). However, it was within an hour of the earthquake that almost the entire site was submerged to a depth of up to nine metres by a series of tsunami waves.

Fukushima Nuclear Accident Investigation Commission (Internet 4) composed of experts independent of plant owner (Tokyo Electric Power Company) reported that a safe emergency shutdown was achieved within seconds of the earthquake. The control rods were fully inserted, and all 13 diesel generators started as per design when tremors disconnected the grid connection. Instrumentation was working correctly, 


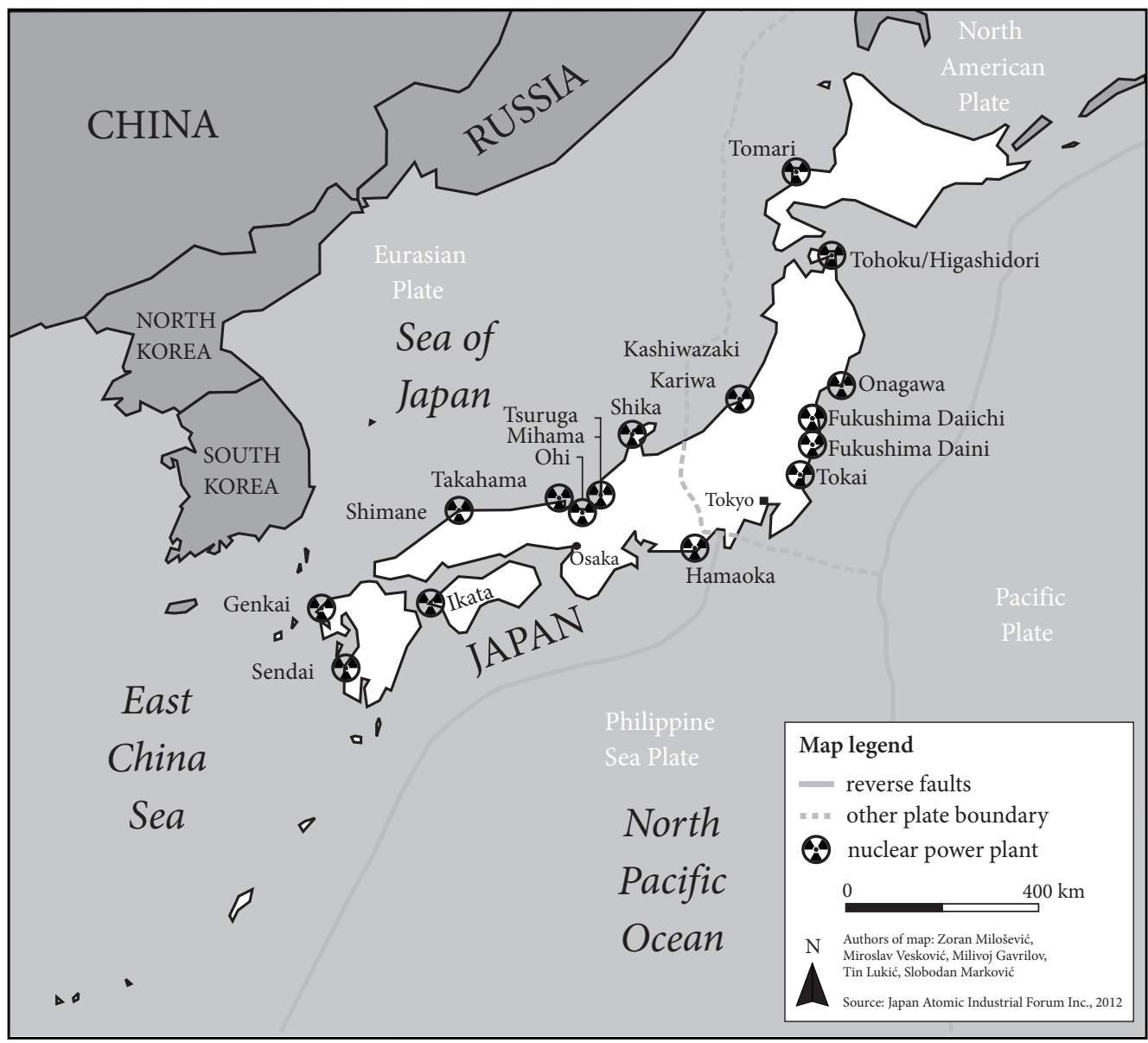

Figure 1: Distribution of nuclear power plants in Japan and area plate tectonics.

as were the cooling systems. However after tsunami waves submerged the plant, the unpowered emergency cooling could no longer adequately remove the decay heat from the reactor units. In hindsight, a reasonably confident statement can be made that the designers did not anticipate that a tsunami generated by an earthquake would disable the backup systems that were supposed to stabilise the reactor after the earthquake.

The World Nuclear News interpreted this report and testified that »the official investigation established tsunami as the direct cause of the accident, and dismissed the idea that the earthquake damage was a major factor in the accident « (Internet 5). The conclusion is based on the interim report issued in December 2011 (Internet 6). The updated report was available only in Japanese at the time of writing this paper (Internet 7).

In response to the situation, some experts (Ritch 2011) and also analysts (Monbiot 2001) even gave favorable accounts of the plant safety system, which although of an old design, coped well with an earthquake of exceptional magnitude, and advocated that the accident should in fact raise the public trust in nuclear plant safety.

However, in spite of such opinions and the »tsunami linkage«, authorities and governments worldwide embarked on making radical changes to their nuclear policies, although aware of the fact that their power reactors could never be subjected to a similar natural disaster. 


\section{Post-Fukushima changes in nuclear energy policy - country-by-country}

Following Fukushima, a series of policy changes were made across the globe. These policy changes differ from country to country to an extent unjustifiable by any country's »specifics «, and only demonstrate the level of influence of various interest groups and political factions, who use various methods to exert pressure on policy makers. They may use the crisis to shape public attitudes, exaggerating the dangers of radioactive pollution, and engaging in social amplification of risk. Following the "never waste a good crisis « mantra, the Daiichi accident was widely used as a platform for anti-nuclear lobbying and changing national energy strategies, policies and safety regulations, most of the time unrelated to any lesson learned from the Fukushima accident.

Facing protests and public pressure, both Germany and Switzerland announced that they would phase out their nuclear power plants, and imposed new taxes on the industry (Germany). German decision was quick, and largely politically driven. It was only eight months earlier that they announced plans to extend the operating life of country's nuclear reactors to 2036 (Internet 11). In Italy a referendum was held in June 2011, to a similar »nuclear exit « effect (Internet 12). Belgium, where nuclear power contributes with over 50\% to domestically produced electricity, did not react immediately, but in July 2012 the announced plans to close its two nuclear plants in 2015 (Internet 15). Bulgaria cancelled the plans to build its Belene nuclear power station and are considering moving one Russian reactor already built at Belene to Bulgaria's only nuclear site Kozloduy (Internet 13). Outside Europe, Venezuela's plan to build a new nuclear power station with Russian assistance was cancelled (Internet 14). These several countries have now joined Australia, Austria, Denmark, Greece, Ireland, Latvia, Lichtenstein, Luxembourg, Malta, Portugal, New Zealand, Norway, and Spain in the list of countries with anti-nuclear policies (Internet 19).

In contrast, France with its 58 nuclear plants in 2010, and the United States with 104 remain champions of nuclear energy (Internet 20). France is per capita the largest nuclear power producer, but today it is locked in a national debate over a partial nuclear phase-out (Internet 17). The United Kingdom appeared to stay firmly on the nuclear power route after Fukushima (Internet 9 and Internet 10). In June 2011, only three months after Fukushima, they identified eight sites for the construction of new nuclear facilities by 2025 . In the US, the construction of new reactors also suffered, but this was less caused by public opposition, and more by energy economics. Even before Fukushima, the advent of shale gas with the new discoveries, new technology and prospective abundance of inexpensive natural gas reserves, and a shortage of financing for projects with escalating construction costs, suggested that nuclear renaissance may be over. While in 2007 U.S. utilities applied to the Nuclear Regulatory Commission to build 28 nuclear-power plants before 2020, it is estimated that now if more than 3 come online before 2020, it would be a major accomplishment (Internet 22 and Internet 23). China is the leader in terms of construction plans, with 26 reactors in the pipeline. However, China suspended approvals of new reactor construction while conducting a lengthy nuclear-safety review. The nuclear capacity projections for 2020 subsequently dropped by about $30 \%$ (Internet 24). Another China's bottleneck is the lack of trained nuclear technicians: Beijing needs to graduate 6,000 nuclear experts a year, while they may be producing only 600 (Internet 25). India, another large potential nuclear market, faces different setbacks in local opposition, and concerns about foreign nuclear reactors aimed at preventing new reactor imports. India's plan to start the first of two Russian-designed reactors in 2011 in tsunami-prone Tamil Nadu state was delayed after Fukushima, when local residents staged a series of starvation strikes. Under similar pressure the local government to abandon a major Russian project in Haripur, in the nearby state of West Bengal, and the completion of the large French reactor at Jaitapur is uncertain too (Internet 25). Russia's nuclear plans seem to be unaffected by Fukushima. Its nuclear power fleet comprises 33 operating reactors, ten new ones are under construction, 17 are planned and another $26 »$ officially« proposed (Internet 26).

\section{Developing World - unaffected by Fukushima}

While the developed world is moving away from nuclear power, that is not the case in the developing world. As prospects for reactor sales in world's advanced economies reduced, nuclear vendors turned to less developed and potentially lucrative markets in the Middle and Far East. World Nuclear Association (Internet 18) gives a useful country-by-country account on their nuclear programmes: 
- South Korea, which made its debut as a nuclear exporter with a20 billion deal to build four reactors in the United Arab Emirates, seems to be quite resolute.

- Russia, meanwhile, is attempting to build on its reactor work at Bushehr (Iran) and construct at least four additional large reactors in Iran.

- Saudi Arabia announced after Fukushima that it intends to spend $\$ 112$ billion to buy 16 reactors, and the necessary nuclear infrastructure by 2030.

- Finally, Turkey, were Russians are already building one reactor, has a bid open for another, and plans to complete 18 more by 2030 .

- Russia is also bidding for new projects in Bangladesh, India and Vietnam, while US, France, Japan, and South Korea are all working to close contracts in Jordan, Vietnam, Turkey, and Saudi Arabia. Moreover, China continues to expand Pakistan's reactor fleet.

In the developing world, therefore, the nuclear energy decisions seem to be much less affected by Fukushima, although this is where nuclear safety is the primary area of concern. None of the nuclear customers in the developing world has adequate nuclear-safety regulatory system. Except Pakistan, they do not have enough trained technicians to build or operate large nuclear-power programs (Sokolsky, 2011).

Nuclear proliferation is yet a separate issue. Over 45 countries that do not use nuclear power today are seriously considering its adoption; of these, 37 are classified by the World Bank as developing nations, while another four countries, Bangladesh, Belarus, Turkey, and Vietnam, are expected to start construction of their nuclear facilities in the near future (Internet 16). The economic development of those countries will require new power generation facilities, and some of this will have to be nuclear. The question is how to make nuclear power available to developing countries without increasing proliferation risks. This is a separate and a comprehensive topic that merits studying on its own, but it is certain that combating proliferation will be associated with increased security measures and increased cost of nuclear power.

\section{Conclusion}

Apart from the rarely mentioned Windscale event in Britain in 1957, the world has so far seen three grave nuclear reactor accidents: Three Mile Island in the United States in 1979, Chernobyl in 1986, and now Fukushima. Each accident was unique, and previously not envisaged as possible. Nuclear engineers have learned from each accident how to improve reactor design in order to reduce the likelihood of that particular accident repeating itself. However, one may think that there would always be new unknowns, and that one accident will be succeeded by another, unwinding in a way that was not foreseen.

Accordingly, some use the lesson of Fukushima to confirm their previous stance that nuclear energy is inherently dangerous. For others, however, Fukushima does not classify nuclear energy as inherently unsafe, because this was an event unique to the Japanese context; they conclude from Fukushima that what the industry needs is more supervision and control. The middle ground is probably occupied by the position expressed by US Congressman E. J. Markey "regulators should consider a moratorium on locating nuclear plants in seismically active areas, require stronger containment vessels in earthquake-prone regions and thoroughly review the plants that use similar technology to the damaged Japanese reactors" (Broder 2011).

In terms of nuclear plant safety assessment, the Fukushima accident may globally be of little relevance, but it has nevertheless brought national policies on nuclear energy into the limelight, with nations lining up on the either side of the debate.

The efforts to reduce consumption of fossil fuels, and the continuing rise in national energy demands provide powerful motivators in the search for alternative energy sources. As a result, many countries have determined that the benefits of nuclear power outweigh the risks, and see nuclear energy as a necessary stepping stone whilst alternative technologies are developed. Some, however, in the wake of Fukushima, have decided that the dangers are simply too great.

The authors fully recognise the importance of nuclear power in any future energy scenario, and hold a view that research and engineering efforts should continue in order to expand nuclear power use in a safe and socially acceptable manner. 


\section{Acknowledgment}

This research paper was supported by Project 176020 of the Serbian Ministry of Education and Science. The authors are grateful for the support of Djordjije Vasiljević, M. Sc. for technical assistance.

\section{References}

Broder, J.M. 2011: U.S. Nuclear Industry Faces New Uncertainty, Internet: http://www.nytimes.com/ 2011/03/14/science/earth/14politics.html (4.9.2012)

Klein, N. 2007: The Shock Doctrine. The rise of disaster capitalism. Toronto.

Monbiot, G. 2011: Why Fukushima made me pro nukes. Guardian. Internet: http://www.smh.com.au/opinion/politics/why-fukushima-made-me- pro-nukes-20110322-1c4qk.html (3.9.2012)

McKenzie, D., Jackson, J. 2012: Tsunami earthquake generation by the release of gravitational potential energy. Earth and Planetary Science Letters 345-348. Amsterdam. DOI: 10.1016/j.epsl.2012.06.036

Perrow, C. 1999: Normal Accidents: living with high-risk technologies. Princeton.

Ritch, J. 2011: The Fukushima Mistake: The challenge of responding wisely. Rosatom 3rd International Forum. Moscow. Internet: http://npsglobal.org/eng/home-mainmenu-1/147-articles/1007-fukushimamistake-challenge-responding-wisely.html (4.9.2012).

Siegrist, M., Visschers, V. H. M. 2012: Acceptance of nuclear power: The Fukushima Effect. Energy Policy (in press). DOI: 10.1016/j.enpol.2012.07.051

Sokolski, H. 2011: Nuclear power goes rogue. Internet: http://www.npolicy.org/article.php?aid=1123\&tid=5 (4.9.2012).

Internet 1: http://www-pub.iaea.org/MTCD/publications/PDF/RDS1_31.pdf (3.9.2012).

Internet 2: http://www-ns.iaea.org/tech-areas/emergency/ines.asp (3.9.2012).

Internet 3: http://www.washington post.com/national/japanese-scientist-fukushima-meltdown-occurredwithin-hours-of-quake/2011/05/26/AGYXSJCH_story.html (29.8.2012).

Internet 4: http://naiic.go.jp/en/report/ (20.8.2012).

Internet 5: http://www.world-nuclear-news.org/RS_Earthquake_not_a_factor_in_Fukushima_accident_0212111.html (20.8.2012).

Internet 6: http://icanps.go.jp/eng/interim-report.html (20.8.2012).

Internet 7: http://www.tepco.co.jp/en/press/corp-com/release/2012/1205638_1870.html (20.8.2012).

Internet 8: http://earthquake.usgs.gov/earthquakes/world/10_largest_world.php (5.9.2012).

Internet 9: http://www.imeche.org/knowledge/industries/energy-environment-and-sustainability/ news/UK-Fukushima-Interim-Report (22.8.2012).

Internet 10: http://www.hse.gov.uk/nuclear/fukushima/interim-report.pdf (22.8. 2012).

Internet 11: http://www.bbc.co.uk/news/business-18420698 (20.8.2012).

Internet $12 \mathrm{http}: / /$ www.bbc.co.uk/news/world-europe-13741105 (4.9.2012).

Internet $13 \mathrm{http}: / /$ www.reuters.com/article/2012/04/11/bulgaria-nuclear-idUSL6E8F4B9320120411 (4.5.2012).

Internet 14: http://www.bbc.co.uk/news/world-latin-america-12768148 (3.9.2012).

Internet 15: http://www.world-nuclear-news.org/NP-Belgian_reactors_learn_their_fate-0507127.html (4.5.2012).

Internet 16: http://www.thebulletin.org/web-edition/roundtables/nuclear-option-the-developingworld-weighs-energy-needs-and-security-risks (4.5.2012).

Internet 17: http://www.guardian.co.uk/world/2012/aug/28/nuclear-row-splits-french-government?newsfeed=true (3.9.2012).

Internet 18: http://www.world-nuclear.org/ (4.5.2012).

Internet 19: http://www.radiationtruth.org/nuclear-power-free-countries/ (4.5.2012).

Internet 20: http://www.euronuclear.org/info/encyclopedia/n/nuclear-power-plant-world-wide.htm (4.5.2012).

Internet 21: http://www.bbc.co.uk/news/world-17546420 (4.5.2012).

Internet 22: http://www.npolicy.org/article.php?aid=1123\&tid=5 (4.5.2012).

Internet 23: http://www.world-nuclear.org/info/inf41.html (4.5.2012). 
Internet 24: http://www.world-nuclear.org/info/inf63.html (4.5.2012).

Internet 25: http://www.thedailybeast.com/newsweek/2011/11/27/post-fukushima-nuclear-power-changes-latitudes.html (4.5.2012).

Internet 26: http://www.world-nuclear.org/info/inf45.html\#Extending_nuclear_capacity_ (4.5.2012).

Internet 27: http://www.jaif.or.jp/english/news_images/pdf/ENGNEWS02_1330597193P.pdf (4.5.2012). 